\title{
THE EFFECT OF COMPLICATIONS AFTER HIP FRACTURE ON REHABILITATION
}

\author{
J. F. KEATING, C. M. ROBINSON, C. M. COURT-BROWN, M. M. MCQUEEN, J. CHRISTIE
}

The complication rates in hip fracture surgery are generally high (Jensen, Sonne-Holm and Tøndevold 1980; Kofoed and Alberts 1980; Clark and Sadr 1985), and further operations are often required to deal with them. We examined the effect of revision operations for early postoperative complications on subsequent rehabilitation.

Patients and methods. Complications requiring further surgical intervention developed within three months of the initial surgery in $71(3.7 \%)$ of 1904 consecutive patients with hip fractures. The original injuries were ten undisplaced and 39 displaced subcapital fractures and 22 peritrochanteric fractures. The undisplaced subcapital fractures had been treated with Asnis screws (Howmedica, Rutherford, New Jersey) and the peritrochanteric fractures with sliding hip screws. The displaced subcapital fractures had been treated by hemiarthroplasty in 31 cases (bipolar in 3), and by total hip arthroplasty in eight. Comparisons of the pre- and postoperative levels of mobility and residential status were used to measure rehabilitation.

Results. At the time of review 30 of the 71 patients $(42 \%)$ had died. The peritrochanteric and the undisplaced subcapital fractures were revised for fixation failure (24) or infection (8). Secondary fixation in six of the noninfected cases failed again in three. Infection was treated by early wound excision and was successful in four patients. In the other four it recurred and the implant was ultimately removed. One of these developed established infected nonunion.

The displaced subcapital fractures were revised for

J. F. Keating, FRCS Ed(Orth), Senior Orthopaedic Registrar

C. M. Robinson, FRCS Ed, Registrar

C. M. Court-Brown, MD, FRCS Ed(Orth), Consultant Orthopaedic Surgeon

M. M. McQueen, FRCS Ed(Orth), Senior Lecturer and Consultant Orthopaedic Surgeon

J. Christie, FRCS, Consultant Orthopaedic Surgeon

Orthopaedic Trauma Unit, Royal Infirmary of Edinburgh, 1 Lauriston

Place, Edinburgh EH3 9YW, UK.

Correspondence to $\mathrm{Mr}$ J. F. Keating.

(C) 1993 British Editorial Society of Bone and Joint Surgery

$0301-620 X / 93 / 6 R 81 \$ 2.00$

J Bone Joint Surg [Br] 1993; 75-B:976.

Received 26 June 1992: Accepted after revision 30 September 1992 recurrent dislocation (22), infection (15) or femoral shaft fracture (2). There were 29 revision arthroplasties (15 total replacements, 14 hemiarthroplasties) eight of which developed recurrent dislocation and four of which became infected. Ultimately, 19 patients with displaced subcapital fractures had an excision arthroplasty, constituting $48 \%$ of this group of patients.

Before the fracture $56(79 \%)$ of the 71 patients could walk independently or with the aid of one stick. At the end of their rehabilitation only 17 of the 41 survivors could do so. Forty-seven $(66 \%)$ of the patients were living at home before the fracture but after treatment only 25 returned home. Sixteen $(50 \%)$ patients treated for peritrochanteric or undisplaced subcapital fractures were living at home after their rehabilitation whereas only ten $(26 \%)$ of those who initially had displaced subcapital fractures were at home (Kruskal-Wallis analysis of variance, $p<0.02$ ).

The mortality rate was $28 \%$ at six months and $36 \%$ at one year after the fracture.

Discussion. If a revision operation has to be undertaken in the early postoperative period after fixation of a hip fracture the prognosis is very poor, particularly in patients who have had a displaced subcapital fracture, half of whom ultimately require an excision arthroplasty.

A previous study from our unit showed that $75 \%$ of patients returned home after hip fracture (Foubister and Hughes 1989). In the subgroup reported here less than $50 \%$ of patients returned home. These results emphasise the importance of minimising complications associated with the original surgical procedure.

No benefits in any form have been received or will be received from a commercial party related directly or indirectly to the subject of this article.

\section{REFERENCES}

Clark DW, Sadr B. Dislocation following Thompson arthroplasty performed through the McFarland-Osborne approach to the hip. J Bone Joint Surg [Br] 1985; 67-B:153.

Foubister G, Hughes SPF. Fractures of the femoral neck : a retrospective and prospective study. $J R$ Coll Surg Edin 1989; 34:249-52.

Jensen JS,Sonne-Holm S, Tendevold E. Unstable trochanteric fractures : a comparative analysis of four methods of internal fixation. Acta Orthop Scand 1980; $51: 949-62$.

Kofoed H, Alberts A. Femoral neck fractures: 165 cases treated by multiple percutaneous pinning. Acta Orthop Scand 1980; $51: 127$ 36. 